\title{
THERMAL TOURISM AS A DRIVER OF LOCAL DEVELOPMENT, AN ILLUSTRATION OF OPPORTUNITIES AND CONSTRAINTS. CASE STUDY OF HAMMAM-GUERGOUR IN THE PROVINCE OF SÉTIF, ALGERIA
}

\author{
Lahcene FERTAS* \\ University Ferhat Abbes, Institute of Architecture and Earth Sciences, \\ Geography Department, Setif 1, Algeria, e-mail: lahcenefort@gmail.com \\ Mohamed ALOUAT \\ Laboratory of History, Civilization and Applied Geography, \\ Ecole Normale supérieure de Bouzereah, Algeria, e-mail: alouat.mohamed@ensb.dz \\ Hamid BENMAHAMED \\ University Ferhat Abbes, Institute of Architecture and Earth Sciences, \\ Geography Department, Setif 1, Algeria, e-mail:hamidbenmahamed@yahoo.fr
}

\begin{abstract}
Citation: Fertas, L., Alouat, M., \& Benmahamed, H. (2022). THERMAL TOURISM AS A DRIVER OF LOCAL DEVELOPMENT, AN ILLUSTRATION OF OPPORTUNITIES AND CONSTRAINTS. CASE STUDY OF HAMMAMGUERGOUR IN THE PROVINCE OF SÉTIF, ALGERIA. GeoJournal of Tourism and Geosites, 40(1), $136-143$. https://doi.org/10.30892/gtg.40116-812
\end{abstract}

\begin{abstract}
Algeria is the largest country in the Mediterranean Basin, but it have classified at the bottom of the ranking in terms of tourism's share of GDP. It is a pristine tourist destination that has unfortunately not been sufficiently exploited, This paper attempts to analyse and understand the dilemma between an incompatible natural potential and the persistence of the proven delay of touristic development by the case study of a mountain municipality of Hammam Guergour. Which is well known for its mineral springs, and which in turn has contributed to the activity of thermal tourism. We used the (SWOT) method which allows internal and external analyses of Thermal tourism. SWOT analysis is used to exploit the opportunities for development in the region, and then how development actors can outperform. The aim is to determine how force factors are used to take advantage of opportunities for development in the region, and then how development actors can overcome weaknesses and then push back threats. We noted striking disparities between the more or less structured spaces in the high plains of the Sétif region, such as the Sétif - El Eulma axis; and a deconstructed mountain space, because the implementation of activities and equipment's does not respond to the existing constraints of Hammam Guergour.
\end{abstract}

Key words: thermal tourism, SWOT analysis, Hammam-Guergour, local development

\section{INTRODUCTION}

\section{A promising tourism potential in slow motion}

The tourism industry became the fastest growing industry in the world. Although tourism has long been considered one of the structuring components of the tertiary sector, it has remarkably evolved towards the secondary sector. The latter has significantly boosted tourism, which has notably contributed to the economic development of several countries. Tourism today represents an economic activity employing $10 \%$ of the world's workforce for more than a billion tourists. In 2017, tourism increased exponentially by 7\%, the highest increase in seven years (UNWTO, 2018). Therefore, tourism has become an essential economic sector and a development driver, an important source of income, and an alternative for many countries and regions using attraction strategies and facilities to attract visitors with rapidly changing expectations (Gwiazdzinski et al., 2019). International organizations, including the World Bank, the European Union, and the World Tourism Organization, recognize international tourism as a promising development sector. International tourism could be a powerful tool to directly address the poverty issues, especially in developing countries (Caire and Le Masne, 2007). The United Nations declared 2017 as the International Year of Tourism for Sustainable Development. In fact, sustainable tourism development is defined as the tourism sector's ability to stimulate economic growth by creating jobs, attracting investment and fostering entrepreneurship, while helping to preserve ecosystems and biodiversity and protect cultural heritage (UNCTAD, 2017). During the 2011-2014 period, Northern Africa was one of the top tourist destinations on Africa. This region recorded the highest number of international tourist arrivals, reaching $47 \%$ of the total tourist arrivals on the continent (UNCTAD 2017). Algeria is a practically an unknown tourist destination which, unfortunately, remains under-exploited, unlike other Mediterranean countries. Indeed, this country possesses an important tourist potential capable of creating an important and successful tourism industry (Herouat, 2012). This largest country of the Maghreb ranks lowest regarding its tourism sector's contribution to GDP, ranked

\footnotetext{
* Corresponding author
} 
111th out of 184 countries, far behind Tunisia (49th) and Morocco (38th). Indeed, the latest report of the World Tourism and Travel Council (WTTC) highlights the stagnation of the tourism sector as it contributed to the GPD with $2.5 \%$ in 2017. Therefore, Algeria's tourism activity remains the lowest among the 12 Mediterranean countries (Cheriet et al., 2016). The Algerian State has long been the exclusive actor in the investment and management of the tourist sector.

The extent of the caused damage led to the emergence of a new perspective on this sector that has long been neglected and even underestimated. A difficult economic and financial crisis affecting Algeria since June 2014 (the drastic drop in oil prices from almost 120 dollars a barrel to 26 dollars with the appearance of covid 19), led decisionmakers to consider a new alternative to promote the tourism sector using the appropriate tools available.

\section{Promising tourist potential}

Algeria is at 2 hours flight from Europe, offering exceptional assets: a sunny Mediterranean climate, a very vast space, unique landscapes, and varied historical sites. With its multiple, African, Mediterranean and Eastern regions, it offers a trilogy of landscapes: the sea, the mountains and the desert. The Algerian coastline extends over 1600 kilometers with vast beaches of fine sand and a sea warmer than in Italy or Spain. The mountainous inlands are more favorable to hiking and adventure tourism Kelfaoui et al., 2021) Indeed, the Djurdjura Massif, offers alpinism and skiing opportunities during the winter period. The Algerian Sahara, one of the most beautiful places in the world, covers an area of 2 million $\mathrm{Km}^{2}$. Moreover, the Hoggar and the Tassili, home of an ancient civilization, is a unique tourism gem. The Algerian Thermal springs are

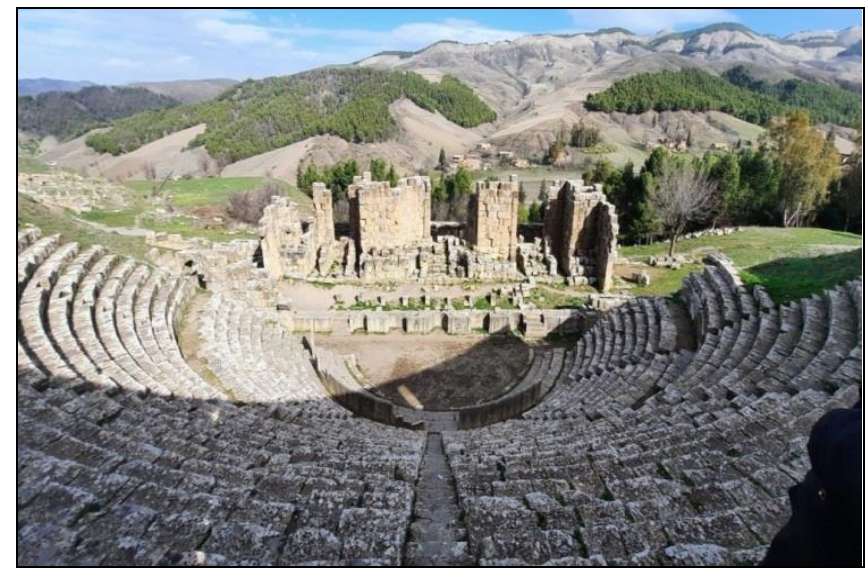

Figure 1. Roman theater of Djemila (North of Algeria) classified as a World Heritage Site (Source: Authors, 2020) located in the mountains, on the northern border, from east to west, attracting mainly local tourists (Widmann, 1976). The thermal tourism may be an interesting domestic tourism option in Algeria, given its therapeutic virtues that promote real investment and development opportunities, and the abundance of natural sources throughout the country. This tourism type fits perfectly as a sustainable tourism that does not require one season, unlike seaside or Saharan tourism, and therefore it offers sustainable attractiveness opportunities. The thermal assessment, carried out in 2015, identifies 282 thermal springs, spread over 38 provinces of the national territory, more than 200 hot springs are listed in the Northern part of the country (Bendaikha and Larbi, 2012).

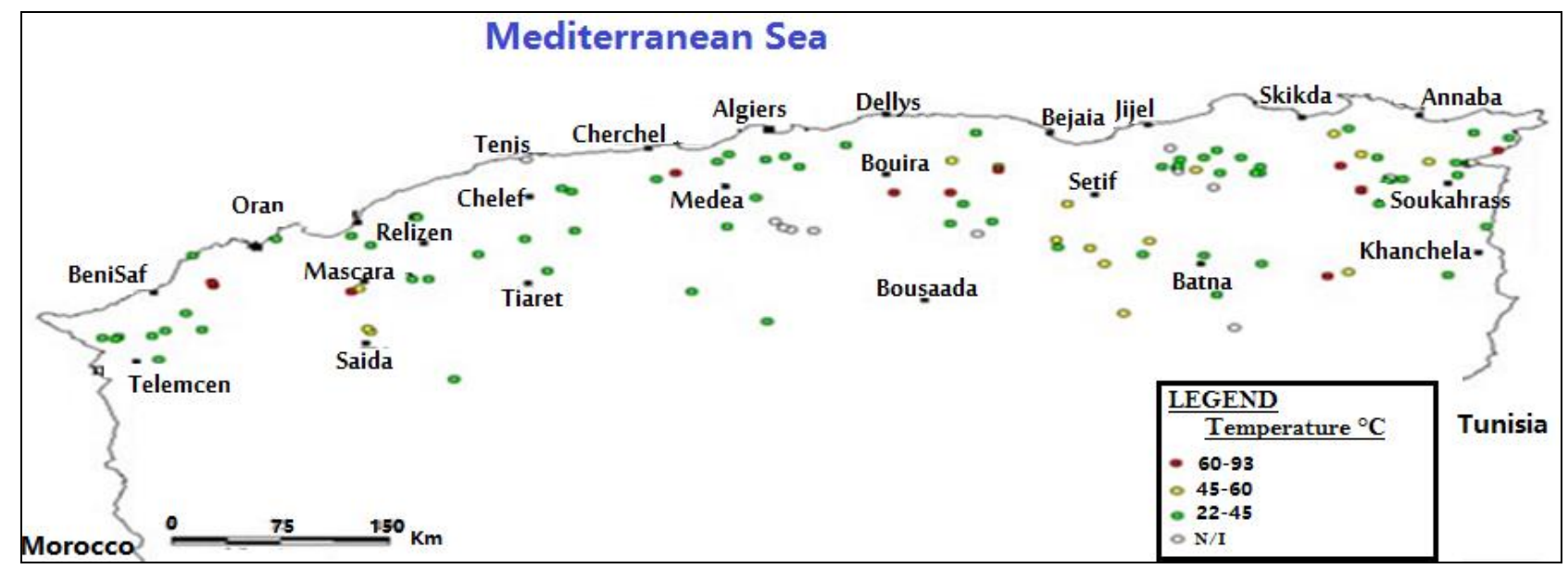

Figure 2. Temperature of main thermal springs in Algeria (Source: Fekraoui and al., 2000)

For the Arabian society, thermal therapy is both religious and medical (Boufassa, 2018). Marriage preparation is traditionally performed at the Hammam (traditional baths). Indeed, this is where wedding rituals are celebrated according to customs and traditions (Zirari, 1993). It is believed that the Hammam is surrounded and inhabited by the Sollah or the Salihine, commonly called in the society's cultural fabric - the good spirits of places and waters. The infertile women pray intercession and pledge (Adel and Benghabrit, 2014). Dekhlat-el-Hammam, which means the entrance to the Hammam, is a popular passage in all life events: birth, circumcision, marriage. The Hammam is a special place to relax, as it representgood hygiene, purification, well-being and the strengthening of social relationships.

"Bathing" is subject to specific rules based on the Qur'an and the Hadith of the Prophet (pbuh). In fact, measures are implemented to ensure that bathing and all forms of relationships between men and women in this place are properly managed (Benkheira, 2010). The separation between men and women is strict, except for married couples proven by a civic act. Our study concerns Hammam Guergour, also called Hammam Sidi-El-Djoudi, a spiritual leader to whom the Zaouia is dedicated - a word that also comes from the Arabic word (inzawa), meaning "to withdraw from the outer world" and refers to a 
religious place of worship, with rooms reserved for teaching the Holy Quran and meditation. Also, the founding saints of the Zaouia are buried nearby. The bathing ritual is mandatory when visiting the Zaouia. The Hammam-Guergour municipality houses a spiritual religious site and a recognized natural tourist potential: thermal water known worldwide for its therapeutic qualities and a mountainous region expected to be highly visited during all seasons. Policies designed to address significantly the key points affecting the tourism sector in its multiple forms, extending over time and space, and exploiting the advantages and assets it offers, will lead to a coherent and sustainable policy, within the local governance framework that recovers the basic elements of the public service and substitutes the energy sector, a sector long valued and in danger of disappearing in the long run. A local tourism development plan based on sustainability and collaboration with local communities is needed. Finally, we will discuss the local tourism assets of this region, and the risks that threaten its development.

\section{ANALYSIS METHODOLOGY}

\section{Location of the study area}

The municipality of Hammam Guergour is one of the 60 municipalities of Setif province (Figure 3) located at $50 \mathrm{~km}$ north-west of Algiers, covering an area of $85.7 \mathrm{Km}^{2}$, a mountainous region bordered by the Babor and Biban ranges, with steep slopes, dominated mainly by the mountains of Kraim el Ghar and Mount Tafath, reaching over 1600 meters. This municipality is distinguished by its North east sub climate, with a hot, dry summer and a cold, wet winter, with an average annual rainfall of $700 \mathrm{~mm}$ (Mrad et al., 2020). The thermal spring of HammamGuergour is located in the NorthWest of Setif province, on the border of the National Road No 74. It is at the exit of Oued Bousselem's gorges.

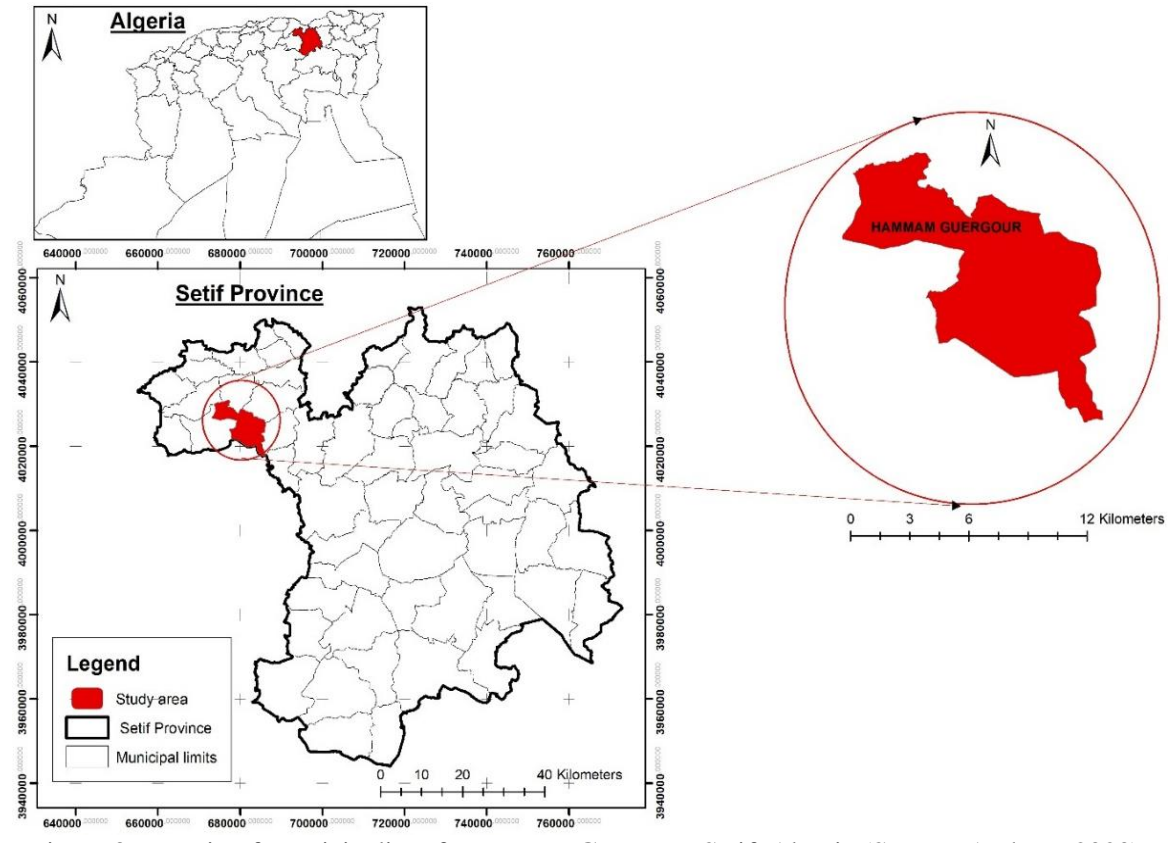

Figure 3. Locatin of Municipality of Hammam Guergour, Setif, Algeria (Source: Authors, 2020)

\section{Aims and challenges:}

This paper aims to answer some relevant questions to understand the particular situation of the Hammam Guergour municipality. In our work, we tackled, on the one hand, the thermal tourism of the municipality, which was not previously examined precisely through time and space, except for the Tourist Development Plan (TDP) by the National Agency for Tourism Development. On the other hand, we attempt to conduct an in-depth analysis to explain the existing gap between the region's natural potential and the perpetuation of a delay in local development. We will highlight the factors preventing the economic and social development of the Hammam Guergour community and its future, following the World Tourism Organization's charter stating that "tourism must be ecologically sustainable in the long term, economically viable and ethically and socially equitable for the local population (Rouzet and Seguin, 2010; Venzal, 2012). To this aim, the following questions were asked:

- What are the strengths and weaknesses of Hammam Guergour's tourism potential?

- What are the constraints that hinder the expansion of thermal tourism in this region?

- How can thermal tourism become a driver for the region's local development?

A discussion aiming to introduce a policy integrating thermal tourism in the dynamics of the Hammam Guergour's local development enables a coherent and balanced functioning in the short, medium and long term. Finally, we outline the actions likely to boost the development and enhancement of local tourism assets and promote its potential over time. We also highlight the contribution of local actors to transform the municipality into a tourism destination.

\section{Analysis method}

We used the case study as a research strategy, with a literature review and data collection. The main results include the identification of the interrelations and impacts that exist between the region of Setif and Hammam Guergour in particular, to determine the reasons of tourism development the failures (region and micro-region). To better focus our work and to distinguish all the strengths, weaknesses and opportunities that prevent the tourism development of Hammam Guergour municipality, we used the SWOT analysis (Strengths, Weakness, Opportunities, Threats) to establish a comprehensive diagnosis that helps in the decision-making of an effective tourism development strategies.

\section{RESULTS AND DISCUSSION}

\section{The SWOT analysis of the tourism in Hammam Guergour:}

The SWOT analysis allows to collect and to intersect the internal and external factors of the region. The aim of this 
technique is to determine the way in which the strength factors are used to properly exploit the development opportunities of the region, and then to determine ways in which development stakeholders can overcome the weaknesses and threats. The analysis is organized along two axes as follows Table 1.

\subsection{The historical, natural and therapeutic assets and potentials of the region}

The Hammam Guergour is a historical place where the emergence of thermal groundwater is the founding factor of the agglomeration, and allowed ancient civilizations to flourish for a long period of time. Ruins buried under the current urban network together with the few vestiges attest to an ancient Roman city that flourished more than 2500 years ago. Thus, the Roman city that had developed near its sources bore the name of: Sava.

Remains of this city are found in this region: vestiges, (pipes, swimming pools) a mausoleum and several Christian inscriptions including a memoria of the martyrs Rogatianus Donatus, Garg (ilius) (Camps, 2000). The region holds a dense forest potential, as the Ouled Rezoug and Babors forests in the North-East of the region. The Babors Natural Reserve, covering an area of $2367 \mathrm{Ha}$, is one of the most important natural reserves in the country. It hosts a rich and rare species of flora and fauna. The studies and research work record no less than 416 plant species. This is the only area in North Africa apart from the Rif forest in Morocco (PAW de Sétif, 2008).

Table 1. SWOT analysis of the tourism in Hammam Guergour

\begin{tabular}{|c|c|}
\hline ASSETS & HANDICAPS \\
\hline $\begin{array}{l}\text { STRENGTHS } \\
\text { 1. Hammam Guergour is a place of history and gathering, besides } \\
\text { being a hammam. } \\
\text { 2. A rich forest potential with a rich fauna and flora. } \\
\text { 3. The Boussellam wadi, both a hydrological and tourism asset, } \\
\text { crossing the municipality and the urban center. } \\
\text { 4. The natural radioactivity of the thermal waters of Hammam } \\
\text { Guergour is recognized worldwide. } \\
\text { 5. The thermal spring offers multiple therapeutic and medical } \\
\text { benefits. } \\
\text { 6. Hammam Guergour holds an important and varied accommodation } \\
\text { potential compared to other stations in the region. }\end{array}$ & $\begin{array}{l}\text { WEAKNESSES } \\
\text { 1. The municipality's landscape is rugged, making it difficult } \\
\text { to access and circulate, together with limited urban land. } \\
\text { 2. The irrational exploitation the thermal waters reservoir can } \\
\text { jeopardise its development. } \\
\text { 3. Contamination risks and physicochemical degradation of } \\
\text { water quality. } \\
\text { 4. Limited economic return of the station. } \\
\text { 5. Poor touristic image of the places and local ruins on the } \\
\text { marketing networks. } \\
\text { 6. Poor management compromised the economic and tourism } \\
\text { development. }\end{array}$ \\
\hline $\begin{array}{l}\text { OPPORTUNITIES } \\
\text { 1. A unique geographical location qualified as a crossroads and } \\
\text { transit point. } \\
\text { 2. An important demographic potential. Setif is the second largest } \\
\text { province with about } 02 \text { million inhabitants }(2018) \text {, behind Algiers. } \\
\text { 3. a well-known thermal destination with } 09 \text { stations scattered in the } \\
\text { North and South of the region. } \\
\text { 4. Important archaeological sites and monuments. } \\
\text { 5. Raising awareness of thermal tourism potential by the Algerian } \\
\text { State, and the regional administration. }\end{array}$ & $\begin{array}{l}\text { THREATS } \\
\text { 1. The region is at risk from seismic activity. } \\
\text { 2. Pollution affecting the ecosystem of Oued Boussellam. } \\
\text { 3. Forest fires threaten the silvo-tourist balance. } \\
\text { 4. The isolation of the municipality hinders local dynamics. }\end{array}$ \\
\hline
\end{tabular}

The Babors forest is a well-preserved source of biodiversity, a place of endemic fauna and flora such as the Cedrus Atlantica Manetti, the Populus termula, the Abies numidica and Sitta ledanti vielliard (Zerroug, 2012). The rich flora and fauna of the region is concentrated in Jebel Babor, highest massif at $2004 \mathrm{~m}$ above sea level (Bounar, 2018). The Oued Bousellam is the main hydrographic axis of the Setif area, characterized by an average monthly flow varying seasonally, with a maximum in February at $56 \mathrm{~m}^{3} / \mathrm{s}$, and a minimum in August at $1.1 \mathrm{~m}^{3} / \mathrm{s}$. The river crosses the cliffs of Hammam Guergour to finally reach Wadi Sahel, possesses 36\% of fish species of continental Algerian waters (15 species) (Bacha and Amara, 2007). The word "thermal" is derived from the Latin "thennae", and the Greek "thermos", meaning hot. Several definitions were attributed to thermal waters; they are based mainly on their temperature (Schwenke, 2007). A mineral water can be considered "thermal" when its surface temperature is higher than a conventional minimum value associated with the average annual air temperature of the area. Thermalism refers to all activities related to the use and exploitation of thermal waters (Flurin, 1999). It is the natural therapy that aspires to the treatment of pathologies for a lasting rehabilitation of the individual (Di Patrizio et al., 2016).

Thermalism is, therefore, all the activities associated with use and exploitation for therapeutic purposes of certain natural mineral springs. The highly radioactive thermal waters of Hammam Guergour place them in first place in Algeria and in fourth place in the world after the baths of Brembach (Germany) and the Jachimov baths in ex-Czechoslovakia and the baths of Ischia Island in Italy (Table 2). This radioactivity results from the content of uranium, radium and potassium dissolved by the waters as they flow through the rocks. Hammam Guergour waters are well known for their ability to heal old wounds and other therapeutic purposes (PAT). Indeed, these (calcium sulfate enriched in sodium chloride), offer the opportunity to develop a very varied thermal and medical care pack, (Table 3). The Hammam Guergour thermal station holds 96 Rooms, 38 Bungalows and 04 villas, with 02 therapeutic swimming pools, showers and baths, massage and thermal baths cures. Two others traditional Hammams on the right bank of Oued Boussellam, one for women, the other for men, mainly for personal hygiene, are divided into 02 to 03 rooms: a dressing room, a resting room at ambient temperature and a high temperature sweating room. 
Table 2. Classification of the richest mineral waters in some countries based on their radioactivity level (radon) in 1938 (Source: Kebir, 2017)

\begin{tabular}{|l|l|c|}
\hline Source Radioactive mineral water & \multicolumn{1}{|c|}{ Countries } & Radioactivity in nanocuries \\
\hline Neuquelle & Brembach (Germany) & 305 \\
\hline Wemerlauf & Jachimov (Czechoslovakia) & 240 \\
\hline Altromishe & Ile d'Ischia (Italy) & 193 \\
\hline Hammam Guergour & Guergour (Algeria) & 122 \\
\hline Grabenbackergelle & Castein $\quad$ (Austria) & 80 \\
\hline Arénas & Acnas Lerez (Spain) & 65 \\
\hline Riettquelle & Baden Baden (Germany) & 56.5 \\
\hline Lepape & Luchon (France) & 41.5 \\
\hline Luso & (Portugal) & 33.6 \\
\hline
\end{tabular}

Table 3. Therapeutic purposes of Hammam Guergour (Source: DTWS, 2015)

\begin{tabular}{|c|c|}
\hline $\begin{array}{c}\text { rheumatology and } \\
\text { osteoarticular traumas }\end{array}$ & Dermatology \\
\hline neurology & Gynecology \\
\hline $\begin{array}{c}\text { cardio - arterial } \\
\text { diseases }\end{array}$ & $\begin{array}{c}\text { diseases of the urinary } \\
\text { and metabolic system }\end{array}$ \\
\hline phlebology & $\begin{array}{c}\text { diseases of the digestive } \\
\text { and metabolic system }\end{array}$ \\
\hline $\begin{array}{c}\text { psychosomatic } \\
\text { affections }\end{array}$ & $\begin{array}{c}\text { Respiratory and ENT } \\
\text { conditions }\end{array}$ \\
\hline
\end{tabular}

4.3 Opportunities and assets of the region

Generally, the areas frequented by tourists' cross administrative boundaries and involve territories that also play a role in the construction of the territorydestination. Also, tourists can exploit several administrative territories (Hankinson, 2010). The Setif region is surrounded by six provinces: to the east, the province of Mila; to the west, the province of

Table 4. Distribution of Hammams according to municipalities in the Sétif region (DTWS, 2013)

\begin{tabular}{|c|l|l|c|c|}
\hline Municipality & \multicolumn{1}{|c|}{ Station } & Exploitation & $\begin{array}{c}\text { Accomodation } \\
\text { capacity }\end{array}$ & Effectives \\
\hline Hammam Guergour & Thermal Complex & Modern & 96 & 22 \\
\hline & Traditional Hammam & traditional & 12 & - \\
\hline Hammam Sokhna & Hammam Lekhder Belmihoub & Modern & 28 & 21 \\
\hline & Hammam ArabTarem & Modern & 14 & 11 \\
\hline & Hammam Mekhlouf Belazem & Modern & 24 & 08 \\
\hline & Hammam Al Sokhna & Traditional & 20 & 12 \\
\hline El - Hamma & Hammam Sidi Amer & Traditional & - & - \\
\hline Mezloug & Hammam Ouled Yelles & Traditional & 20 & 18 \\
\hline Ouled Tebbane & Hammam Sidi Mansour & Traditional & - & - \\
\hline Total & $\mathbf{0 9}$ & & $\mathbf{2 1 2}$ & $\mathbf{9 2}$ \\
\hline
\end{tabular}

Bordj-Bou-Arréridj; to the north, Béjaia and Jijel; and to the south, M'Sila and Batna. The region occupies a strategic position and forms a transit area crossed by the East-West highway, the national road RN5, the railway line East-West, and the 8 May 1945 airport, offering 8 air links. They are considered as main arteries and structuring axes at the national level, offering the region better accessibility and a mediating image. It has a significant demographic weight with an estimated population of around 02 million inhabitants (DPSB, 2018). It is the second most populated province after Algiers, the capital of the country. Approximately $55 \%$ of its population is under 30 years old and it covers an area of $6,549.64 \mathrm{~km} 2$, with an average density of 292 inhabitants per km2. Also, this area offers an important thermal springs potential with 09 resorts between modern and traditional (Table 4), divided into 04 centers: Hammam Guergour, Hammam Sukhna, Hammam Ouled Tebbane and Hammam Ouled Yelles. These tourist sites are capable of transforming the Setif region's image towards a thermal tourist destination that offers a development perspective of thermal tourism.

The region holds an important archaeological heritage site and historic monuments, like the Historic Site of Djemila (Figure 4) one of the most beautiful Roman ruins in the world and included in the UNESCO World Heritage since 1982. The Ain Lehnech site is $7 \mathrm{~km}$ north of El-Eulma, (Setif region) one of the oldest prehistoric sites in North Africa, discovered by Professor Camille Arambourg in 1947. Recent excavations and paleontological research conducted in 1992 revealed the existence of a prehistoric deposit dating back to the Oldowayen (Sahnouni et al., 2002). The Algerian State awareness concerning the dynamism of thermal tourism is growing. A national strategy has been outlined with guidelines of the master plan of tourist development encouraging public-private partnership and the implementation of an operational funding plan to support tourism activities. Also, the region is home to a business tourism space located along the region's median axis which includes the two main cities (Sétif and El - Eulma).

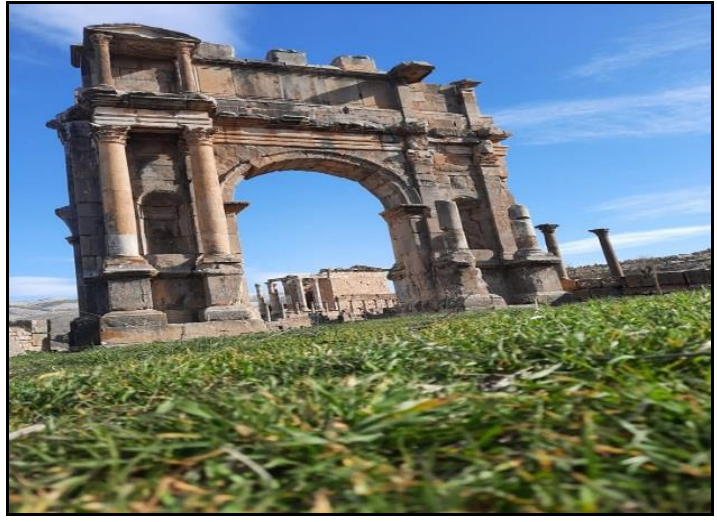

Figure 4. The Cuicul: Roman city theater (Authors, 2020)

\subsection{Weaknesses and threats in the study area}

Hammam Guergour's municipality relief is very rugged. The headquarters of the municipality and the Daïra are based outside the agglomeration of Hammam-Guergour itself. Overlooked by mountains and gorges dug by Oued Boussellam, this area was always considered difficult to access. The deep valleys are often confined to narrow gorges, making accessibility and urban mobility quite challenging. The urban base of the agglomeration is wedged between two mountains divided into two parts by Oued Boussellam. They are connected by a pedestrian bridge and another mechanical bridge. Traffic jams are very heavy and congested. The unsustainable exploitation of thermal waters in the municipality of Hammam Guergour is the biggest threat to this fragile and vulnerable resource, with a 2\% annual population growth rate (2018). This over exploitation is stressed by the fact that it's the only source of

income for local inhabitant. Contamination risks and degradation of the physicochemical quality of water, through the use of chemical fertilizers in agriculture, and the unregulated water resource exploitation and industrial discharges are 
increasing. Indeed, Oued Bousellam. Chemical pollution by ammonium contents that reached a rate of $4.4 \mathrm{mg} / \mathrm{l}$, a nitrite value of $2.43 \mathrm{mg} / \mathrm{l}$, iron $2.06 \mathrm{mg} / \mathrm{l}$ and bacteriological contamination $230.10^{3}$ UFC /100ml 2011) aggravate the environmental situation (Sersoub, 2012). The economic return of the state-owned station is limited. In 2018, the station reported a 162 million DA revenue. During the same year, the station received 61846 visitors with a $63 \%$ average annual rate of accommodation. Compared to the station of Hammam Sokhna in the southern part of the region, which received nearly 180,000 visitors in 2018 (Reporters 2019), it is three times more than the Hammam Guergour station.

On the other hand, we also note the lack of medium-range hotel capacity (1, 2, stars), thus demonstrating the recourse of certain visitors to book overnight stays in apartments owned by the local inhabitants, providing them with additional income. In addition, it is difficult to quantify the income and the number of visitors at the two traditional Hammams, as payment is made without a ticket. The place's image transmits thoughts without linguistic use. Indeed, images are likely to awaken the attraction of the potential tourist towards an appealing destination. One of the leading works in tourism studies. The Tourist Gaze (Urry and Larsen, 2011) emphasizes the role of iconography in modern tourism practices (Bernadou, 2017). Hammam Guergour is lacking a tourist image of its places and local vestiges on the advertisement networks due to insufficient tourism and travel agencies that provide marketing and commercialization. Added to this, the absence of infrastructure is a major constraint to any kind of development and investment, where even local residents are struggling to cope. Finally, the tourist iconography of Hammam Guergour still requires development.

\subsection{Threats and risks hindering local development}

The region is prone to seismic activity varying from 3.9 to 5 degrees on the Richter scale. It is part of the GuergourAnini network, cited by (Vila, 1980), as a reverse fault system of various orientations, N-S, E-W, NE-SW. These are neotectonic faults affecting recent Quaternary deposits ranging from $5.71 \mathrm{~km}$ to $14.28 \mathrm{~km}$ in length. Based on the seismicity analysis of Northeast Algeria, this fault network is considered potentially active (Harbi et al., 2003). The Bousellam river crossing Hammam Guergour urban center is at risk of pollution throughout the year due to the various waste water discharges from the urban centers (Sheikh Laayfa, Sétif, Mezloug, and Hammam Ouled Yelles). The watercourse has become the outlet of industrial units lacking water treatment and filtering systems.

Also, the agricultural chemicals used by the farmers as pesticides and fertilizers, passively contribute to the vulnerability and the deterioration of the wadi's aquatic ecosystem. Recurrent forest fires threaten the silvo-touristic balance of the region. Indeed, several fires have occurred in the region of Hammam Guergour, on 23 June and 1 July 2020, one in the forest of Jebel Ayad, with an estimated area destroyed at 544 ha. Forestry professionals attribute the responsibility for most of the fires to human activities. The most numerous interface zones are at the start of a fire (Belkaid and Carrega, 2012). For a long time, Algerian forests (Figures 5 and 6) paid a high price for fires in times ofpolitical disturbance (Marc, 1916). The Algerian Prime Minister, Mr Djerad, mentioned that: "the hypothesis of a criminal act has not been ruled out". Sometimes, fire is necessary to maintain certain forest ecosystems, but for tourists, it is a loss of a sense of nature, walking, cycling, the disappearance of places for relaxation and leisure, making it difficult to restore the silvo-tourist balance of burnt-out areas".

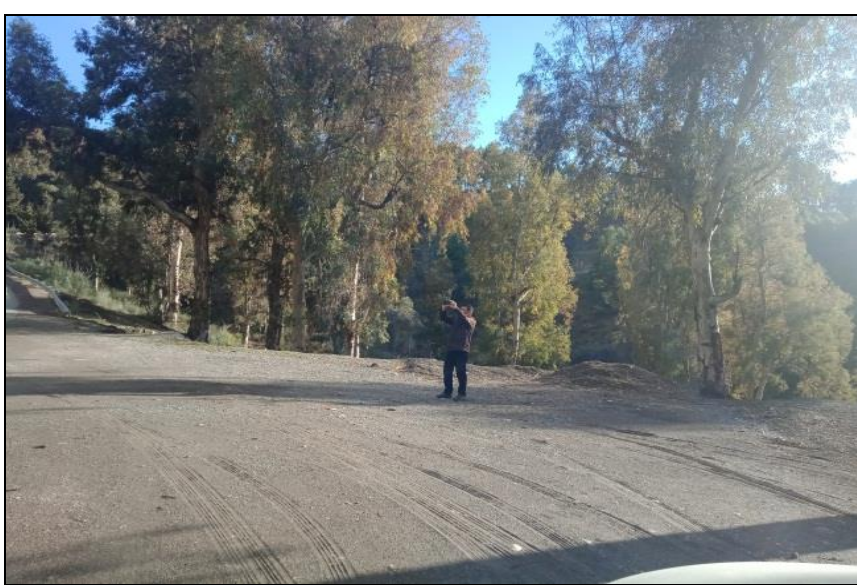

Figure 5. The Babors Forest (Source: Authors 2021)

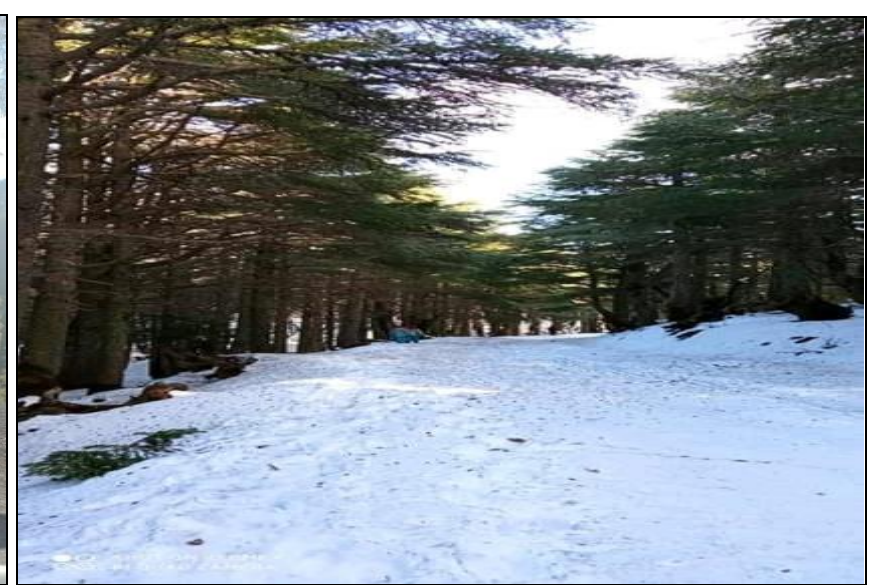

Figure 6. The Babors Forest (Source: Authors 2020)

Circulation is essential for tourists activities, yet the geographically remote municipality of Hammam Guergour is only crossed by only by national road R N 74, connecting Setif - Béjaia, and often prone to landslides and the hazards of the climate. Also, the transportation means are terribly scarce, especially at the end of the day. All infrastructures are located in the plains and valleys, while mountainous sectors were left isolated, poorly connected to modern means, away from the centers and cities (Côte, 2011). Effective management is a process that requires flexibility and transparency. It is designed to integrate multiple interests between public and private partners. It involves the sharing of resources through coordination and cooperation (Vodoz, 2013). It should be noted that, given the potential of the region, we believe that the level of economic and social development is beneath its natural and scenic resources. This prompts questions about the local governance system in the region. It involves a type of local management unsuited to the 
economic and social changes the country is experiencing, and can be explained by a weak democracy of elected officials, who rarely were elected on the basis of their individual competences, but rather on the basis of popularist and tribal considerations, and partisan divisions that lead imperatively to the blocking of the system of decision making within the local assembly. Also, and for decades, in the past, the State remained the sole manager of thermal tourism, so, the legislation has for a long time slowed down the initiative of the local private actors in terms of tourism investment.

\section{CONCLUSIONS}

The municipality of Hammam-Guergour faces a striking paradox due to its rich natural and cultural tourism potential, and its poor and repulsive environment. The territory of the municipality experiences a discrepancy between the natural capacities of thermal water resources and the inherent infrastructures in the study area; as well as striking disparities between the more or less structured spaces in the highlands of the region of Setif, for example the axis Setif El-Eulma; and other unstructured spaces. These disparities are related to the disadvantaged experience of the development and the isolation of the local population. The reality proves that the thermal tourism development and the rural tourism in general in a mountainous isolated municipality such as Hammam Guergour, is regarded as difficult, because the implementation of activities and equipment do not respond to the existing natural or economic constraints. It requires the physical (dangerous roads) and digital development and accessibility to the municipality.

There are alternatives emerging that promote local skills and human intelligence to overcome stagnation. Balance and diversify tourist activities by focusing on the mountain environment, through the improvement of accommodation capacities, as well as developing mini-parks for families and installing cable cars connecting the peak of the Fertla Massif to the urban center of Guergour, while protecting the local ecosystem. The persistence of local particularities (thermal, mountain, cultural), clearly shows that tourism can be an important factor in the transformation and evolution of these features. In spite of the mountainous aspect dominating the municipality, the development of this area is the result of human activity. In the future, local decision-makers should be able to assess the situation (Cheniki and Baziz, 2020), by measuring the impacts of local tourism, and obtain a global and proportionate vision of the situation.

\section{REFERENCES}

Adel, K., \& Benghabrit Remaoun, N. (2014). Hammam: pratiques et rituels aujourd'hui [Hammam: practices and rituals today]. Insaniyat. Revue algérienne d'anthropologie et de sciences sociales, (63-64), 59-82. https://doi.org/10.4000/insaniyat.14582

Bacha, M., \& Amara, R. (2007). Les poissons des eaux continentales d'Algérie. Étude de l'ichtyofaune de la Soummam [Freshwater fish of Algeria. Study of the ichthyofauna of the Soummam River]. Cybium, 31(3), 351-358. https://doi.org/10.26028/cybium/2007-313-004

Bendaikha, W., \& Larbi, S. (2012). Hybrid fuel cell and geothermal resources for air-conditioning using an absorption chiller in Algeria. Energy Procedia, 28, 190-197. https://doi.org/10.1016/j.egypro.2012.08.053

Belkaid, H., \& Carrega, P. (2012). Interface habitat/forêt: enjeu et facteur de risque incendie [Habitat / forest interface: stake and fire risk factor]. In SHS Web of Conferences (Vol. 3, p. 01003). EDP Sciences. https://doi.org/10.1051/shsconf/20120301003

Benkheira, M.H. (2007). Nudité et ordre moral dans l'islam médiéval'II [The Hammam, Nudity and Moral Order in Medieval Islam II]. Revue de l'histoire des religions, 3, 320-71. https://doi.org/10.4000/rhr.5783

Bernadou, D. (2017). Construire l'image touristique d'une région à travers les réseaux sociaux: le cas de l'Émilie-Romagne en Italie [Image building and social network: the use of pictures to promote the Emilia-Romagna region as a tourist destination]. Cybergeo: European Journal of Geography, 43. https://doi.org/10.4000/cybergeo.28481

Boufassa, S. (2018). Architecture des établissements thermaux en Algérie durant le XIXe siècle. Reflet ethnocentrique du système colonial [Architecture of thermal establishments in Algeria during the nineteenth century]. Diacronie. Studi di Storia Contemporanea, $(33,1)$. https://doi.org/10.4000/diacronie. 7283

Bounar, R. (2018). Etude de potentialités biologiques cartographie et aménagement de la chaine des babors dans la démarche du dévlopement durable [Study of organic potential mapping and development of the babes chain in the approach of sustainable devolution]. Doctoral dissertation.

Caire, G., \& Le Masne, P. (2007). La mesure des effets économiques du tourisme international sur les pays de destination [Measuring the economic effects of international tourism on destination countries]. Marche et organisations, (1), 63-88. https://doi.org/10.3917/maorg.003.0063

Cheniki, K., \& Baziz, A. (2020). Evaluating the ability of local municipalities to promote strong brand image in Algerian cities. GeoJournal of Tourism \& Geosites, 28(1). https://doi.org/10.30892/gtg.28102-449

Camps, G. (2000). Hammam Guergour. Encyclopédie berbère, 3350-3352. https://doi.org/10.4000/encyclopedieberbere.1649

Cheriet, K., Medila, Z., \& Khenchouche, N. (2016). Gestion du chantier d'un projet architectural a usage touristique [Management of the site of an architectural project for tourist use]. http://hdl.handle.net/123456789/7491

Côte, M. (2011). L'Algérie, mondialisation et nouvelles territorialités [Algeria : globalization and new territorialities]. Méditerranée. Revue géographique des pays méditerranéens/Journal of Mediterranean geography, (116), 77-84. https://doi.org/10.4000/mediterranee.5406

Di Patrizio, P., Boulangé, M., \& Kanny, G. (2016). Médecine générale et médecine thermale, partenaires d'une médecine holistique [General medicine and crenotherapy, partners of a holistic medicine]. La Presse thermale et climatique, 153, 149. http://www. socmedthermale.org/presse-thermale-et-climatique/\#53-67-wpfd-2016-p2

Fekraoui, A., Kedaid, F.Z., Rezig, M., \& Abouriche, M. (2000). Atlas des ressources géothermiques du nord de l'Algérie [Atlas of geothermal resources in northern Algeria.]. Internal report, Centre de Développement des Energies Renouvelables, Algiers, Algeria. https://www.cder.dz/download/jnv2_3.pdf

Flurin, R. (1999). L'Antiquité, le Moyen Âge et la Renaissance. Première partie: Le thermalisme dans l'Antiquité [Antiquity, the Middle Ages and the Renaissance. Part 1: Hydrotherapy in Antiquity]. Presse thermale et climatique, 136(3), 165-173.

Gwiazdzinski, L., Cholat, F., Tritz, C., \& Tuppen, J. (2019). Tourisme (s) en mouvement (s) entre adaptation, résilience et changement de paradigme [Tourism (s) in motion between adaptation, resilience and paradigm shift]. https://halshs.archives-ouvertes.fr/halshs-02064504

Hankinson, G. (2010). Place branding theory: A cross-domain literature review from a marketing perspective. Towards Effective Place Brand Management, Edward Elgar, Cheltenham (UK), 149-164. https://hdl.handle.net/10171/35457 
Harbi, A., Maouche, S., \& Benhallou, H. (2003). Re-appraisal of seismicity and seismotectonics in the north-eastern Algeria Part II: 20 th century seismicity and seismotectonics analysis. Journal of seismology, 7(2), 221-234. https://doi.org/10.1023/A:1023571316216

Herouat, F.Z. (2012). Comment promouvoir le tourisme en Algérie? [How to promote tourism in Algeria?]. Doctoral dissertation. http://dspace.univ-tlemcen.dz/bitstream/112/4693/1/harouat-fatima.mag.pdf

Kelfaoui, A., Rezzaz, A.M., \& Kherrour, L. (2021). Revitalization of mountain rural tourism as a tool for sustainable local development in Kabylie (Algeria). The case of Yakouren municipality. GeoJournal of Tourism and Geosites, 34(1), 112-125. https://doi.org/10.30892/gtg.34115-626

Marc, P. (1916). Les incendies de forêts en Algérie. Notes sur les forêts de l'Algérie[Forest fires in Algeria. Notes on the forests of Algeria]. Typographie Adolphe Jourdan. Imprimeur-libraire-Editeur, Alger.

Mrad, D., Dairi, S., Boukhari, S., \& Djebbar, Y. (2020). Applied multivariate analysis on annual rainfall in the northeast of Algeria. Journal of Water and Climate Change, 11(4), 1165-1176. https://doi.org/10.2166/wcc.2019.272

Rouzet, E., \& Seguin, G. (2010). Marketing du tourisme durable [Sustainable tourism marketing]. Dunod. https://doi.org/10.3917/ dunod.rouze.2010.01

Sahnouni, M., Hadjouis, D., Van Der Made, J., Canals, A., Medig, M., Belahrech, H., \& Rabhi, M. (2002). Further research at the Oldowan site of Ain Hanech, North-eastern Algeria. Journal of Human Evolution, 43(6), 925-937. https://doi.org/10.1006/jhev.2002.0608

Schwenke, A. (2007). De l'usage de l'eau thermale en nébuliseur [The use of thermal water in a nebulizer]. Doctoral dissertation, UHPUniversité Henri Poincaré).

Sersoub, D. (2012). Aménagement et Sauvegarde de la Biodiversité de la Vallée d'Oued Boussellem* Sétif [Development and Protection of Biodiversity in the Oued Boussellem Valley* Sétif]. Doctoral dissertation, Université de Sétif 1-Ferhat Abbas.

Urry, J., \& Larsen, J. (2011). The tourist gaze 3.0. Sage. https://uk.sagepub.com/en-gb/eur/the-tourist-gaze-30/book234297

Vila, J.M. (1980). La chaîne alpine de l'Algérie orientale et des confins algéro-tunisiens[The Alpine chain of eastern Algeria and the Algerian-Tunisian borders]. Doctoral dissertation Universite Pierre et Marie curie.

Venzal, C. (2012). Fondements et principes de la valorisation touristique d'un géosite: évaluation et interprétation des géosites de la Réserve naturelle géologique de Haute-Provence (France)[ Foundations and principles of the tourist promotion of a geosite: evaluation and interpretation of the geosites of the Geological Reserve of Haute Provence (France)]. Géocarrefour, 87(3-4), 239-248. https://doi.org/10.4000/geocarrefour.8852

Vodoz, L. (2013). Gouvernance et participation [Governance and participation] (No. BOOK_CHAP, pp. 171-183). Lausanne, SZ: Presses polytechniques et universitaires romandes. https://infoscience.epfl.ch/record/197747

Widmann, M. (1976). Le tourisme en Algérie [Tourism in Algeria]. Méditerranée, 25(2), 23-41. https://doi.org/10.3406/medit.1976.1663

Zerroug, K. (2018). Elaboration d'un système d'information géographique (flore) dans la wilaya de Sétif [Development of a geographic information system (flora) in the wilaya of Sétif]. Doctoral dissertation.

Zirari, H. (1993). Quête et enjeux de la maternité au Maroc: étude ethno-culinaire [Quest and challenges of motherhood in Morocco: ethno-culinary study]. Doctoral dissertation, Paris, EHESS.

***CNUCED, (2017). Tourisme au service d'une transformation inclusive (Tourism for an inclusive transformation) Africa Economic Development Report.

***DTWS, (2018) Hammam Guergour; Tourism Development Plan, Preliminary Report, National Tourism Agency.

***DTWS. (2013). Master plan for tourism development in Setif province.

*** UNCTAD (2017). Economic Development in Africa Report 2017: Tourism for Transformative and Inclusive Growth. https://unctad.org/en/PublicationsLibrary/aldcafrica2017_en.pdf

*** UNWTO (2018) Report on Tourism and Culture Synergies.

*** DPSB (2018) Monograph of the wilaya of Sétif. Algeria.

*** UNCTAD (2017). Economic Development in Africa Report 2017: Tourism for Transformative and Inclusive Growth. https://unctad.org/en/PublicationsLibrary/aldcafrica2017_en.pdf

Article history: Received: 07.09.2021 Revised: 09.12.2021 Accepted: 12.01.2022 Available online: 02.02.2022

